\title{
STUART AND GEORGIAN MOMENTS
}

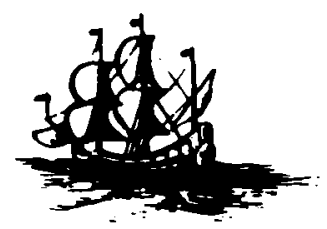

Published under the auspices of The 17th and 18th Centuries Studies Group University of California, Los Angeles 


\section{Publications of \\ The 17th and 18th Centuries Studies Group, UCLA}

1.

Seventeenth-Century Imagery: Essays on Uses of

Figurative Language from Donne to Farquhar

Edited by Earl Miner

2.

England in the Restoration and Early Eighteenth Century

Essays on Culture and Society

Edited by $H$. T. Swedenberg, Ir.

3.

Stuart and Georgian Moments: Clark Library Seminar Papers on Seventeenth and Eighteenth Century English Literature

Edited by Earl Miner 


\section{STUART AND GEORGIAN MOMENTS}

CLARK LIBRARY SEMINAR PAPERS ON SEVENTEENTH AND EIGHTEENTH CENTURY ENGLISH LITERATURE

EDITED BY EARL MINER

1972

UNIVERSITY OF CALIFORNIA PRESS

Berkeley - Los Angeles • London 


$$
\begin{aligned}
& \text { University of California Press } \\
& \text { Berkeley and Los Angeles, California } \\
& \text { University of California Press, Ltd. } \\
& \text { London, England }
\end{aligned}
$$

Copyright $\odot 1972$ by The Regents of the University of California ISBN: 0-520-01641-6

Library of Congress Catalog Card Number: 78-100020

Printed in the United States of America 
For

Lawrence Clark Powell

from bis fortunate friends 



\section{Foreword}

The 17th and 18th Centuries Studies Group has been founded at the University of California, Los Angeles, with the aim of bringing together students of various disciplines to advance understanding of the lives and the culture of peoples during a crucial period of human experience. To this end the group has undertaken a variety of enterprises (with the support of the Chancellor and the deans at UCLA), including teaching programs, conferences, and symposia designed to cross departmental lines. The aim is to foster studies involving numerous disciplines and to encourage participation by other universities in the United States and abroad. One such enterprise is the publication of a series of books covering a wide spectrum of interests and attracting contributors in various fields.

The group hopes to draw upon the libraries, talents, and resources of one university in a way that will engage the efforts and be worthy of the attention of a more than local fraternity of scholars. Individual volumes are planned to pursue a variety of topics. We welcome comments and suggestions from scholars interested in these two centuries and hope that our endeavors will stimulate comparable study and activity at other universities.

Maximillian E. Novak

Chairman, The 17tb and 18th

Centuries Studies Group, UCLA 



\section{Preface}

The dozen essays reprinted here by the 17th and $18 \mathrm{th}$ Centuries Studies Group, University of California, Los Angeles, have been chosen from among the papers read at invitational Saturday seminars at the William Andrews Clark Memorial Library and originally published in pamphlet form. The principle of selection excluded not only the many papers on subjects not literary but also literary papers that did not deal with the literature of the period here defined. A number of the essays included have proved so popular that they have long since been out of print, and the stock of other pamphlets is nearly exhausted. In addition to the scholarly purpose of republishing these papers as a collection, the 17th and 18th Centuries Studies Group welcomes the opportunity to honor one of its greatest benefactors, Dr. Lawrence Clark Powell. In his capacity as director of the Clark Library and as university librarian, Mr. Powell built up UCLA holdings, on a qualitative as well as a quantitative basis, during difficult as well as some more affluent years. As a lover of company as well as of books, he also initiated the Clark Library Saturday seminars. This subject has been enlarged upon in the sketch of Lawrence Clark Powell contributed to this volume by his successor, Robert Vosper. Few universities have been fortunate enough to enjoy the services of two librarians of such eminence in succession, and it is fitting that in honoring one the other should participate.

Anyone who knows the former librarian of UCLA must be ix 
keenly aware that his achievements are extraordinarily varied. He is an author-probably a more prolific one than any of his professorial colleagues-and an autobiographer. He has a deep love of California and, indeed, of the entire southwestern United States. Certainly the literary and artistic life of the Los Angeles area during the past three or four decades would have been sorely impoverished without his achievements and those of his large circle of gifted friends. Without his puckish wit and his conviviality, many a bright day would have been lost. Without his desire to assist that natural inclination of rare books to move to southern California, the libraries of UCLA would not be so outstanding in quality and number of books as they are. Feeling strongly that the books should be got to UCLA, and then that students and faculty should be got to the books, he sealed, if he did not begin, the tradition of UCLA as a place with efficient and hospitable libraries. Small wonder that he should have implemented his desire to bring people together to talk about books and ideas by inventing one of the most agreeable forms of doing so, the Clark Saturday seminars.

About two weeks before a seminar Saturday one receives in the mail a handsome invitation designed and printed by William Cheney, one of the country's foremost designers of printing. One arrives at the Clark Library about ten o'clock in the morning. The entrance to the library is suitably modest, and the grounds of the estate, which cover a city block, are enclosed by brick walls. Inside, the formal arrangement of the garden struggles with profusion: the strife of art and nature, as the seventeenth century put it. Such poets as Andrew Marvell would also have recognized the brick-walled garden as a bortus conclusus, both literally and emblematically a place for the contemplative soul. Since Los Angeles is a garden in the desert (as well as many other things), the plants on the Clark grounds come from many places. There are box and 
yew from England, a stunning example of the Brazilian jacaranda, many varieties of the Australian eugenia or bush cherry, a splendid tall specimen of the kauri pine from New Zealand, and an imposing Moreton Bay fig, also from the antipodes. The devotee of the Clark Library will find many smaller shrubs, such as the camellia and the agapanthus (both blue and white), and will know that along the walk of the eastern formal garden there is a myrtle hedge of uncommon fragrance. Again in Renaissance and seventeenth-century terms, it is a locus amoeraus, an earthly paradise, especially during times of noise or of busy, interruptive annoy on the UCLA campus.

Before going to the library building, one parks his car in an area adjoining the old carriage house used by the Clark family. Presently it serves as the gardeners' toolshed, provides quarters for Mr. Cheney, and houses a couple who maintain residence at the Clark. The home of the Clark family was a rather plain brick dwelling whose interior was enhanced by lovely wood paneling. The first reaction of everybody who came to the library was that the Clark house should be refurnished and brought back to life, but over the years disuse and termites had reduced it to a somewhat Dickensian ricketiness, perhaps like that of Miss Havisham's house in Great Expectations, and recently it was demolished.

As one enters for the Saturday seminar, one heads by instinct for the parterre, where the Clark staff is busy welcoming guests with goodwill, coffee, and cakes. Usually those among the coffee drinkers who have come from England are busy entreating the sun, as Dr. Johnson put it, while the southern Californians are seeking the shade. The guests vary, depending on the subject of the seminar, but one will meet wives and husbands from different branches of the University of California and from other colleges and universities in the area. One is always happy to see again friends from the Huntington 
Library in San Marino, including both staff members and visiting scholars who are using the facilities of that great library and enjoying its handsome grounds. Almost always there are guests-booksellers, printers, lawyers, other professional and artistic people-whom one can most simply describe as friends of the Clark Library or of its director.

At about eleven o'clock the librarian of the Clark begins to urge the seminar members into the drawing room of this baroque building, which is constructed of travertine and brick on the outside and of wood and marble on the inside. The drawing room is designed after an Italian baroque council chamber. In its ceiling and at one end are pictures illustrative of Dryden's All for Love, with smaller inset pictures illustrating stories in Ovid's Metamorphoses chosen from those translated by Dryden. At the other end is a fresco illustrating Shakespeare's Antony and Cleopatra. The abundance of pink and brown flesh on ceiling and walls may startle visitors who are not familiar with baroque painting, and perhaps even some of those who are, but the decoration is genuinely baroque, or neobaroque, in spirit, a form of the preposterous that wins one's affection. On the walls hang portraits of the library's donor and his first librarian, along with portraits of literary worthies. Dryden smiles with enigmatic detachment; Pope and Cibber avoid each other's gaze; Tom Killigrew, got up in silks, is accompanied by a dog; Nat. Lee's arms cross, his eyes dart, and his whole countenance reveals a heart pierced by unspeakable tragedy.

After the introductions the first speaker reads his paper, and the moderator leads the audience in raising questions or making comments about the topic of the morning. The morning discussion is followed by an alfresco buffet lunch, and at about one-thirty the audience reconvenes in the drawing room for the second paper and the second period of discussion. The seminar is over around three o'clock, and the automobiles be- 
gin to leave the grounds, their drivers assisted by the gardeners and the maintenance men of the Clark Library.

Not everybody leaves the Clark after the seminar. Some stay on, and there are always a few who earlier in the day slip downstairs to the working part of the library while other people are chatting or strolling. What these assiduous spirits are after one can never tell for certain. Perhaps they are Dickensian scholars, for the Clark boasts an extraordinary collection of Dickens published in the original parts, along with other Victorians, especially the Pre-Raphaelites. The Clark's collection of fine printing represents, in addition to the Kelmscott Press, the Cuala Press, and hence includes a Yeats collection; it also offers what is almost a historical survey of the best printing in California. Or the busy scholar may be consulting the Clark's holdings in Montana history, since the family fortune came from that state and the elder Mr. Clark played a major role in early Montana politics. It is more likely, however, that so inquiring a soul will be consulting letters and other materials of Oscar Wilde or Eric Gill, or that he is in. terested in other similar individual collections. It is most likely, however, that he is looking for something listed in Donald Wing's Short-Title Cataloge, or for something published in the ensuing fifty years, because it is in the period from 1640 to 1750 that the special strength of the Clark Library lies. Books, pamphlets, and broadsides from the Civil War period, from the Restoration, and from the age of Pope make up the basic holdings. Science, theology (with many "A Sermon Preach'd"), music, history, editions of the classics, and, above all, literature are heavily represented. The Clark possesses about a quarter of the 80,000 to 90,000 items listed by Wing; it also has a number of titles that are not so listed. All titles are cross-listed with the holdings of the Huntington Library. These two great southern California libraries together probably have all but several dozen Restoration plays. The Clark 
also boasts one of the eight best Milton collections in the country (even without the items held at the Research Library on the UCLA campus). Mr. Clark, a gentleman collector, was free to buy what he thought he ought to-of course he had to have a Shakespeare first folio and a few quartos-or simply what he himself wanted to own. Since he enjoyed Chaucer, the Clark has a surprising strength in early editions. For what reason I do not know, Mr. Clark built his main collection around the author who remains its center, the admirer of Shakespeare, Chaucer, and Milton, the father of English criticism, John Dryden.

It has often puzzled me that most of the outstanding students of Dryden during the past century have not been English, or if English, have left England. Scots, Australians, and above all North Americans predominate. Sir Walter Scott and James Russell Lowell were Dryden's two greatest nineteenthcentury critics, and in the twentieth century the revival of critical interest on the part of T. S. Eliot and Mark Van Doren consisted in writing Scott and Lowell large. Whatever Mr. Clark's reason, it is a fascinating fact that the inheritor of an American fortune should not have gone off to Europe in the approved Jamesian fashion, but instead have stayed home in a formal garden, supported the Los Angeles Symphony almost by himself (legend has it that he was sometimes allowed to play with the second violins), and collected the works of Dryden. With his collection and the endowment to enlarge it, the Clark Library has naturally become the center for the study of Dryden, and in particular for the California Edition started some years ago by the late Edward Niles Hooker and by H. T. Swedenberg. Over the years, Dryden and Milton have frequently been the focus of UCLA seminars taught in the north room of the Clark, though I well remember teaching the metaphysical poets there and noticing one student with Donne's Poems of 1633 spread in her lap. Mr. 
Clark would be pleased to know that his books are used so extensively, by students as well as by established scholars. I have observed, over many years of university teaching, that a graduate student who has held an actual seventeenth-century edition in his or her hand is thereafter set apart from the less fortunate ones who have access only to anthologies, modernspelling texts, or paperbacks.

All of us who are familiar with the Clark Library, and who are fortunate enough to have its relatively small holdings fall into our areas of interest, have been served by a staff unmatched, at least in my experience, for kindliness and helpfulness. All of us have acknowledged their assistance in our books. They and I know how much we owe to Lawrence Clark Powell. It is always a better day for Larry's having been by. We hope that he will accept this tribute as it is meant: 2 gift to him of something that is his own from people who claim him as their own. I speak of these things in the plural because his friends are many.

I acknowledge the permission to reprint freely given by the authors of the papers collected in this volume or, for the much lamented Herbert Davis, by Mrs. Davis. And although he is always the first to help and the last to be thanked, I am grateful to William E. Conway, librarian of the Clark Library, for carefully inspecting the front matter of this book and for helping to prepare copy for the printer. Miss Susan McCloskey deserves my thanks for using part of her Christmas vacation to help prepare the index.

Los Angeles

E. $\boldsymbol{M}$.

Summer, 1971 



\section{Contributors}

Don Cameron Allen is Professor Emeritus of The Johns Hopkins University. His paper was presented in 1964 and published the following year.

Bertrand H. Bronson is Professor Emeritus of the University of California, Berkeley. He presented his paper in 1953. It was published the following year and has long been out of print in the Clark series.

The late Herbert Davis was at one time President of Smith College; he later returned to Oxford and held a chair in bibliography. He was Clark Library Senior Fellow in 1966, and his paper was given and published in that year.

Irvin Ehrenpreis is Professor of English at the University of Virginia. He presented his paper in 1969, and it was published the same year.

Robert Halsband is Professor of English at the University of California, Riverside, and he delivered his paper on the same rainy Saturday that Irvin Ehrenpreis gave his.

Leon Howard is Professor Emeritus of the University of California, Los Angeles. He read his paper in 1958, and it was published in 1959.

Maximillian E. Novak is Professor of English at the University of California, Los Angeles. He spoke on the same day as Herbert Davis.

James E. Phillips is Professor of English at the University of California, Los Angeles. He spoke on the same day as Bertrand $H$. Bronson and later was the first person to give a second paper in the Clark seminar series.

James Sutherland is now retired from the Lord Northcliffe chair of Modern English Literature at University College, London. He was Clark Senior Fellow in 1962-63 and has been a 
welcome visitor to UCLA on several occasions. The paper he gave in 1956 was published the next year.

H. T. Swedenberg, Jr., is Professor of English at the University of California, Los Angeles, and General Editor of the California Edition of The Works of Jobn Dryden. He was the inaugural Clark Professor and held the post from 1969 to 1971. His paper was given and published in 1967.

Robert Vosper is University Librarian at the University of California, Los Angeles, Director of the Clark Library, Professor of Library Service, and sometime President of the American Library Association.

Charles E. Ward is Professor Emeritus of Duke University. He was Clark Senior Fellow in 1967. He spoke on the same day as H. T. Swedenberg, Jr.

Ian Watt is Professor of English and Chairman of the Department at Stanford University. He spoke on the same occasion as James Sutherland. 